\title{
Bio-Efficacy of Different Herbicides on Weed Dynamics, Growth and Grain Yield of Transplanted Rice (Oryza sativa L.) in Odisha, India
}

\author{
Aurobindo Mohanta* and A. K. Behura \\ Department of Agronomy, Institute of Agricultural Sciences, Siksha 'O' Anusandhan \\ (Deemed to be University), Bhubaneswar-751029, Odisha, India \\ *Corresponding author
}

\section{A B S T R A C T}

K e y w o r d s
Pretilachlor, 2,4-D
Ethyl ester,
Bispyribac sodium,
Almix, Penoxsulam,
Vivaya, Fenoxaprop
-p-ethyl,
Pyrazosulfuron
ethyl, Grain yield,
Transplanted rice
Article Info
Accepted:
22 March 2020
Available Online:
10 April 2020

\section{Keywords}

Pretilachlor, 2,4-D

Ethyl ester,

Almix, Penoxsulam

Vivaya, Fenoxaprop

ethyl, Grain yield,

Transplanted rice

Article Info

22 March 2020

Available Online
The field experiment was conducted during kharif, to study the efficacy of different herbicides on weed dynamics, growth and grain yield of transplanted rice (Oryza sativa L.). The experiment was conducted in randomised block design with three replications and ten weed management practices. The treatments were $\mathrm{T}_{1}$-Pretilachlor $(50 \% \mathrm{EC}) @ 0.5 \mathrm{~kg}$ a.i./ha 2 DAT, $\mathrm{T}_{2}$-Pretilachlor (50\% EC) @ 0.5kg a.i./ha 2DAT fb 2,4-D Ethyl ester (38\% EC) @ 0.5kg a.i./ha 21 DAT, T -Bispyribac sodium (10\% SC) @ 0.025kg a.i./ha 21 DAT, $\mathrm{T}_{4}$-Almix (20\% WP) @ 0.004kg a.i./ha 3 \& 21 DAT, $\mathrm{T}_{5}$-Penoxsulam $(21.7 \% \mathrm{SC})$ @ $0.0225 \mathrm{~kg}$ a.i./ha $21 \mathrm{DAT}, \mathrm{T}_{6}$-a premix herbicide combination of Penoxsulam $1.02 \% \mathrm{~W} / \mathrm{W}$ + Cyhalofop butyl 5.1\% W/W @ 0.135kg a.i./ha 21 DAT, T 7 -Fenoxaprop -p-ethyl (9.3\%

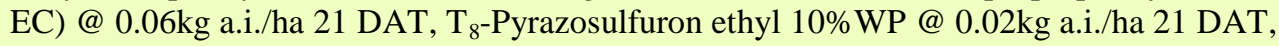
$\mathrm{T}_{9^{-}} 2$ hand weedings at $30 \& 45 \mathrm{DAT}, \mathrm{T}_{10^{-}}$Weedy check. The soil of the experimental site was sandy loam in texture with $\mathrm{pH}$ 6.5. The test variety was "Naveen". The result revealed that at 30 days after transplanting (DAT) weed flora comprised sedges (37.8\%), broad leaf weeds $(29.4 \%)$ and grasses $(32.8 \%)$ and at 60 DAT the weed flora in the same order comprised 39.6, 31.0 and $29.4 \%$, respectively. The highest grain yield (4.92 t/ha) was recorded with 2 hand weeding treatment and $\mathrm{B}: \mathrm{C}$ ratio of 1.71 but in case of postemergence application of penoxsulam + cyhalofop butyl $0.135 \mathrm{~kg}$ a.i./ha gives grain yield of (4.42 t/ha) and $\mathrm{B}: \mathrm{C}$ ratio of 1.89 which is the best herbicide treatment.

\section{Introduction}

In the context of Odisha, rice area, production and productivity is 3.9 million hectare, 9.8 million tonnes and $2.47 \mathrm{t} / \mathrm{ha}$, respectively (Odisha Economic Survey, 2017-18). In order to meet the progressive targeted demand, rice crop should be managed scientifically to get its full yield potential. Among the several factors responsible for low yield of rice, weed competition is one of the major causes of yield reduction. Globally, actual rice yield losses due to pests have been estimated at $40 \%$, of which weeds have the highest loss potential of $32 \%$ (Bastiaans et al., 1997). The worldwide estimated loss in rice yield from 
weeds is around $10 \%$ of the total production (Oerke and Dehne, 2004). Rice grain production in our country is reportedly suffering a loss of 15 million tonnes annually due to weed competition. Moist conditions of the hydromorphic environment in transplanted rice permit rapid growth of weeds. The adoption of high yielding rice varieties with provision of fertilizer and irrigation in the multiple cropping systems also significantly contribute to the weed problems.

In the recent past, a number of pre and postemergence herbicides have been recommended for controlling weeds in transplanted rice. The most common preemergence herbicides used to control weeds in transplanted rice are butachlor, pretilachlor, oxadiargyl, pyrazosulfuron ethyl, pendimethalin, anilophos and post-emergence herbicides are 2,4-D ethyl ester, metsulfuron methyl + chlorimuron ethyl, bispyribac sodium. New formulations of herbicides are also coming to the market through research efforts.

The continuous use of same herbicides having similar mode of action result shift in weed flora and development of herbicide resistance in weeds (Rajkhowal et al., 2006). The weed flora shifted from Echinochloa sp. to Ischaemum rugosum with continuous use of pretilachlor and Caesulia axillaris to Cyperus iria with continuous use of anilophos have been documented (Singh et al., 2005).

\section{Materials and Methods}

The experiment was laid out in the Research Farm of SOADU near to SUM hospital in Khurda district at $20^{\circ} 17^{\prime} 21$ " North latitude and $85^{\circ} 45^{\prime} 51^{\prime}$ " East longitude with an altitude of $25.9 \mathrm{~m}$ above the mean sea level (MSL). The field was homogeneously fertile with even topography.
The soil texture of experimental plot was sandy loam, acidic in reaction, low in nitrogen and phosphorus and medium in potassium and having $\mathrm{pH}$ of 6.5 . The experiment was conducted in randomized block design with three replications and 10 treatments. The individual plot size was $5 \mathrm{~m} \times 4 \mathrm{~m}$. The variety is medium tall in height suitable for irrigated / rainfed medium land in kharif season.

It can tolerate water depth up to $20 \mathrm{~cm}$ at tillering. It is resistant to blast, sheath blight and stem borer. The duration of the variety is 115-120 days with grain yield potential of 5.0 to $6.0 \mathrm{t} / \mathrm{ha}$. Grains are medium bold having test weight of 18.5 to $20.0 \mathrm{~g}$. An uniform fertilizer dose of 80-40-40 kg N- $\mathrm{P}_{2} \mathrm{O}_{5}-\mathrm{K}_{2} \mathrm{O} / \mathrm{ha}$ was applied in experimental field. Nitrogen was applied through urea and $\mathrm{P}_{2} \mathrm{O}_{5}$ as DAP whereas $\mathrm{K}_{2} \mathrm{O}$ was applied through MOP. One third dose of nitrogen and full dose of phosphorus and potash were applied as basal at the time of transplanting and 50\% nitrogen at tillering and rest $25 \% \mathrm{~N}$ at panicle initiation stage.

Crop seeds were treated with carbendazim @ $1.5 \mathrm{~g} / \mathrm{kg}$ seed before sowing to protect the crops from seed borne diseases. Herbicides and different weed management practices were adopted as per treatment. The performance of different treatments was studied in terms of all types of flora, weed density, weed biomass and their subsequent effect on growth and yield of rice. There were 10 treatments. The treatments were presented in Table 1.

\section{Results and Discussion}

\section{Weed flora}

The associated weed flora constituted sedges in highest density followed by grasses and broad leaf weeds. Among the sedges, Cyperus iria, Cyperus difformis, Fimbristylis miliacea, 
Scirpus supinus were the most dominant weeds followed by grasses like Echinochloa colona, Echinochloa crusgalli, Ischaemum rugosum, Commelina benghalensis, Paspalum scrobiculatum. Among the broad leaf weeds Alternanthera sessils, Ipomoea aquatica, Aeschynomene indica, Ludwigia parviflora were the prominent weeds.

Weed population increased up to 45 DAT and thereafter decreased till harvest. Two hand weeding exhibited significant reduction in weed density compared to other treatments at all the growth stages. Among the herbicidal treatments post-emergence application of penoxsulam $1.02 \% \mathrm{~W} / \mathrm{W}+$ cyhalofop butyl $5.1 \%$ W/W (vivaya) controlled the weeds efficiently which was at par with postemergence application of penoxsulam. Weedy check plot exhibited the highest weed density $/ \mathrm{m}^{2}$ at all the stages of crop growth.

\section{Weed control efficiency (WCE in \%)}

Data on weed control efficiency of different treatments was presented in Table 2. The data showed that among herbicidal treatments post emergence application of penoxsulam $1.02 \% \mathrm{~W} / \mathrm{W}+$ cyhalofop butyl $5.1 \% \mathrm{~W} / \mathrm{W}$ $\left(\mathrm{T}_{6}\right)$ registered WCE of 87.7, 81.4, 78.3, 74.8 and $72.9 \%$ at $15,30,45,60$ DAT and at harvest respectively. The highest WCE in penoxsulam + cyhalofop butyl might be due to reduction of weed dry weight at all stages of growth. The lowest weed control efficiency was recorded by almix $\left(\mathrm{T}_{4}\right)$ of 19.9, 14.2, 9.8, 13.5 and $11.3 \%$ at $15,30,45,60 \mathrm{DAT}$ and at harvest, respectively.

\section{Effect of treatments on grain yield, straw yield, harvest index and weed index (\%)}

Data on effect of treatments on grain yield, straw yield, harvest index and weed index (\%) of different treatments was presented in Table 3. The highest grain yield (4.92 t/ha) was recorded with two hand weeding which was statistically at par with post-emergence application of penoxsulam + cyhalofop butyl (4.46 t/ha).

The yield increase by two hand weeding over the best herbicide treatment 'penoxsulam + cyhalofop butyl' was to the extent of $10.3 \%$. The other alternative herbicide of penoxsulam + cyhalofop butyl producing statistically at par yield were penoxsulam @ $0.135 \mathrm{~kg}$ a.i./ha 21 DAT (4.36 t/ha), pretilachlor@ $0.5 \mathrm{~kg}$ a.i./ha 2 DAT fb 2,4-D ethyl ester @ 0.5 kg a.i./ha 21 DAT (4.25 t/ha), pyrazosulfuron ethyl @ $0.05 \mathrm{~kg}$ a.i./ha 21 DAT (4.06 t/ha) and only pretilachlor @ $0.5 \mathrm{~kg}$ a.i./ha 2 DAT (3.99 t/ha).

The straw yield recorded by the two hand weeding (5.75 t/ha) was statistically at par with that of penoxsulam + cyhalofop butyl (5.25 t/ha) and penoxsulam (5.16 t/ha). The straw yield increase by the two hand weeding over penoxsulam + cyhalofop butyl and penoxsulam was 9.5 and $11.4 \%$, respectively. The harvest index value of $45.93 \%$ was recorded under penoxsulam + cyhalofop butyl which was closely followed by two hand weeding (46.11). The HI value was recorded under the treatment weedy check $(46.00 \%)$.

The lowest weed index (WI) value of $21.5 \%$ was estimated with penoxsulam + cyhalofop butyl followed by in increasing order with penoxsulam $(23.23 \%)$, pretilachlor fb 2,4-D ethyl ester (25.2\%), pyrazosulfuron ethyl (28.5\%), bispyribac sodium (32.6\%) and pretilachlor $(29.8 \%)$, fenoxaprop -p-ethyl (40.0\%) and almix (42.1\%). The weedy check treatment showed the highest WI of $73.1 \%$.

Effect of treatment on gross return (Rs./ha), net return (Rs./ha) and B:C ratio

Data on effect of treatment on gross return (Rs./ha), net return (Rs./ha) and B:C ratio of 
different treatments was presented in Table 4. Two hand weeding treatment produced higher gross return of Rs. 91,850/ ha over all other treatments while the lowest was recorded with weedy check of only Rs. 47,245/ ha. The gross return from other promising treatments were penoxsulam + cyhalofop butyl (Rs. 83,300/ ha), penoxsulam (Rs. 81,460/ ha), pretilachlor fb 2,4-D ethyl ester (Rs. 79,385/ ha).

Table.1 Treatment details of the experiment

\begin{tabular}{|c|c|c|c|}
\hline $\begin{array}{c}\text { Treatment } \\
\text { No. }\end{array}$ & $\begin{array}{c}\text { Herbicide Applied/ Weed } \\
\text { management Practices }\end{array}$ & Time of application (DAT) & $\begin{array}{c}\text { Dose } \\
\text { (kg/ha) }\end{array}$ \\
\hline $\mathrm{T}_{1}$ & Pretilachlor (50\% EC) & Pre-emergence & $0.5 \mathrm{~kg}$ \\
\hline $\mathrm{T}_{2}$ & $\begin{array}{c}\text { Pretilachlor (50\% EC) fb 2,4-D Ethyl } \\
\text { ester (38\% EC) }\end{array}$ & $\begin{array}{c}\text { Pre-emergence } f b \text { Post- } \\
\text { emergence }\end{array}$ & $\begin{array}{c}0.5 \mathrm{~kg} f b \\
0.5 \mathrm{~kg}\end{array}$ \\
\hline $\mathrm{T}_{3}$ & Bispyribac sodium (10\% SC) & Post-emergence & $0.025 \mathrm{~kg}$ \\
\hline $\mathrm{T}_{4}$ & Almix (20\% WP) & $\begin{array}{c}\text { Pre-emergence \& Post- } \\
\text { emergence }\end{array}$ & $0.004 \mathrm{~kg}$ \\
\hline $\mathrm{T}_{5}$ & Penoxsulam (21.7\% SC) (Granite) & Post-emergence & $0.0225 \mathrm{~kg}$ \\
\hline $\mathrm{T}_{6}$ & Penoxsulam 1.02\%W/W + & Post-emergence & $0.135 \mathrm{~kg}$ \\
& Cyhalofop butyl 5.1\% W/W & & \\
\hline $\mathrm{T}_{7}$ & Fenoxaprop -p-ethyl $(9.3 \% \mathrm{EC})$ & Post-emergence & $0.06 \mathrm{~kg}$ \\
\hline $\mathrm{T}_{8}$ & Pyrazosulfuron ethyl 10\%WP & Post-emergence & $0.02 \mathrm{~kg}$ \\
\hline $\mathrm{T}_{9}$ & Two hand weeding & $20 \& 40$ & - \\
\hline $\mathrm{T}_{10}$ & Weedy check & - & - \\
\hline
\end{tabular}

$\mathrm{fb}=$ followed by, DAT= Days after transplanting

Table.2 Effect of treatments on weed control efficiency (WCE) per cent

\begin{tabular}{|c|c|c|c|c|c|c|}
\hline \multirow{2}{*}{\multicolumn{2}{|c|}{ Treatment details }} & \multicolumn{5}{|c|}{$\begin{array}{l}\text { WCE calculated at different days after } \\
\text { transplanting (DAT) }\end{array}$} \\
\hline & & 15 & 30 & 45 & 60 & $\begin{array}{c}\text { At } \\
\text { harvest }\end{array}$ \\
\hline $\mathbf{T}_{1}$ & Pretilachlor & 58.6 & 69.5 & 59.1 & 55.5 & 54.4 \\
\hline $\mathbf{T}_{2}$ & Pretilachlor fb 2,4-D ethyl ester & 77.7 & 70.6 & 63.8 & 62.7 & 59.2 \\
\hline $\mathbf{T}_{3}$ & Bispyribac sodium & 32.2 & 30.9 & 25.5 & 26.5 & 25.1 \\
\hline $\mathbf{T}_{4}$ & Almix & 19.9 & 14.2 & 9.8 & 13.5 & 11.3 \\
\hline $\mathbf{T}_{5}$ & Penoxsulam & 85.3 & 75.3 & 74.9 & 70.9 & 66.4 \\
\hline$T_{6}$ & Penoxsulam + Cyhalofop butyl & 87.7 & 81.4 & 78.3 & 74.8 & 72.9 \\
\hline $\mathbf{T}_{7}$ & Fenoxaprop -p-ethyl & 25.3 & 28.0 & 21.2 & 21.1 & 19.6 \\
\hline $\mathbf{T}_{8}$ & Pyrazosulfuron ethyl & 72.9 & 50.9 & 61.1 & 57.9 & 52.1 \\
\hline $\mathbf{T}_{9}$ & Two hand weeding & 100 & 100 & 100 & 94.3 & 90.8 \\
\hline $\mathbf{T}_{10}$ & Weedy check & - & - & - & - & - \\
\hline
\end{tabular}


Table.3 Effect of treatments on grain yield, straw yield, harvest index and weed index (\%)

\begin{tabular}{|c|l|c|c|c|c|}
\hline \multicolumn{1}{|c|}{ Treatment details } & $\begin{array}{c}\text { Grain } \\
\text { yield } \\
(\mathbf{t} / \mathbf{h a})\end{array}$ & $\begin{array}{c}\text { Straw } \\
\text { yield } \\
(\mathbf{t} / \mathbf{h a})\end{array}$ & $\begin{array}{c}\text { Harvest } \\
\text { index } \\
\mathbf{( \% )}\end{array}$ & $\begin{array}{c}\text { Weed } \\
\text { index } \\
\mathbf{( \% )}\end{array}$ \\
\hline $\mathbf{T}_{\mathbf{1}}$ & Pretilachlor & 3.99 & 4.68 & 46.02 & 23.3 \\
\hline $\mathbf{T}_{\mathbf{2}}$ & Pretilachlor fb 2,4-D ethyl ester & 4.25 & 5.01 & 45.89 & 13.6 \\
\hline $\mathbf{T}_{\mathbf{3}}$ & Bispyribac sodium & 3.83 & 4.52 & 45.86 & 22.2 \\
\hline $\mathbf{T}_{\mathbf{4}}$ & Almix & 3.29 & 3.88 & 45.88 & 33.1 \\
\hline $\mathbf{T}_{\mathbf{5}}$ & Penoxsulam & 4.36 & 5.16 & 45.79 & 11.4 \\
\hline $\mathbf{T}_{\mathbf{6}}$ & Penoxsulam + Cyhalofop butyl & 4.46 & 5.25 & 45.93 & 10.3 \\
\hline $\mathbf{T}_{\mathbf{7}}$ & Fenoxaprop -p-ethyl & 3.40 & 4.01 & 45.89 & 30.9 \\
\hline $\mathbf{T}_{\mathbf{8}}$ & Pyrazosulfuron ethyl & 4.06 & 4.79 & 45.87 & 17.5 \\
\hline $\mathbf{T}_{\mathbf{9}}$ & Two hand weeding & 4.92 & 5.75 & 46.11 & - \\
\hline $\mathbf{T}_{\mathbf{1 0}}$ & Weedy check & 2.53 & 2.97 & 46.00 & 48.6 \\
\hline & SE(m) \pm & 0.17 & 0.20 & - & - \\
\hline & C.D. (0.05) & 0.51 & 0.61 & - & - \\
\hline
\end{tabular}

Table.4 Effect of treatment on gross return (Rs./ha), net return (Rs./ha) and B:C ratio

\begin{tabular}{|c|l|c|c|c|c|c|c|}
\hline \multicolumn{2}{|c|}{ Treatment details } & \multicolumn{2}{|c|}{ Gross return (Rs./ha) } & $\begin{array}{c}\text { Cost of } \\
\text { cultivation } \\
\text { (Rs./ha) }\end{array}$ & $\begin{array}{c}\text { Net } \\
\text { return } \\
\text { (Rs/ha) }\end{array}$ & $\begin{array}{c}\text { B:C } \\
\text { ratio }\end{array}$ \\
\hline $\mathbf{T}_{\mathbf{1}}$ & Prain & Straw & Total & \\
\hline $\mathbf{T}_{\mathbf{2}}$ & $\begin{array}{l}\text { Pretilachlor fb 2,4-D } \\
\text { ethyl ester }\end{array}$ & 69,825 & 4,680 & 74,505 & 41,515 & 32,990 & 1.79 \\
\hline $\mathbf{T}_{\mathbf{3}}$ & Bispyribac sodium & 67,025 & 5,010 & 79,385 & 42,170 & 37,215 & 1.88 \\
\hline $\mathbf{T}_{\mathbf{4}}$ & Almix & 57,575 & 3,880 & 61,455 & 42,550 & 18,905 & 1.44 \\
\hline $\mathbf{T}_{\mathbf{5}}$ & Penoxsulam & 76,300 & 5,160 & 81,460 & 44,063 & 37,397 & 1.85 \\
\hline $\mathbf{T}_{\mathbf{6}}$ & $\begin{array}{l}\text { Penoxsulam + } \\
\text { Cyhalofop butyl }\end{array}$ & 78,050 & 5,250 & 83,300 & 44,145 & 39,155 & 1.89 \\
\hline $\mathbf{T}_{\mathbf{7}}$ & Fenoxaprop -p-ethyl & 59,500 & 4,010 & 63,510 & 42,335 & 21,175 & 1.50 \\
\hline $\mathbf{T}_{\mathbf{8}}$ & Pyrazosulfuron ethyl & 71,050 & 4,790 & 75,840 & 41,705 & 34,135 & 1.82 \\
\hline $\mathbf{T}_{\mathbf{9}}$ & Two hand weeding & 86,100 & 5,750 & 91,850 & 53,795 & 38,055 & 1.71 \\
\hline $\mathbf{T}_{\mathbf{1 0}}$ & Weedy check & 44,275 & 2,970 & 47,245 & 40,395 & 6,850 & 1.17 \\
\hline
\end{tabular}

NB: Rice grain@ Rs.1750/q and straw @ Rs.1000/t 
Two hand weeding recorded the maximum cost of cultivation of Rs. 53,795/ ha followed by penoxsulam + cyhalofop butyl (Rs. 44,145/ ha), penoxsulam (Rs. 44,063/ ha), bispyribac sodium (Rs. 43,070/ ha). Weedy check treatment incurred the lowest cost of cultivation (Rs. 40,395/ ha). The highest net return was observed with penoxsulam + cyhalofop butyl amounting to Rs. 39,155/ ha followed by in the decreasing order were two hand weeding (Rs. 38,055/ ha), penoxsulam (Rs. 37,397/ ha) and pretilachlor fb 2,4-D ethyl ester (Rs. 37,215/ ha). The lowest net returns of only Rs. 6,850/ ha was observed with weedy check.

The application of penoxsulam + cyhalofop butyl recorded the highest $\mathrm{B}: \mathrm{C}$ ratio of 1.89 followed by sequential application of pretilachlor and 2,4-D ethyl ester (1.88), penoxsulam (1.85), pyrazosulfuron ethyl (1.82), pretilachlor alone (1.79). The lowest $\mathrm{B}: \mathrm{C}$ ratio of 1.17 was obtained in weedy check.

From the findings summarized above, it is abserved that rice variety 'Naveen' under two hand weeding (4.92 t/ha) and post-emergence application of penoxsulam + cyhalofop butyl @ $0.135 \mathrm{~kg}$ a.i./ha $(4.42 \mathrm{t} / \mathrm{ha})$ produced at par grain yield. The variation in grain yield between the above two treatments was only $10.3 \%$. But the high cost of cultivation incurred due to two hand weeding (Rs 53,795 /ha) could not reflect in monetary advantages like net return ( $\mathrm{Rs} 38,055 / \mathrm{ha}$ ) and $\mathrm{B}: \mathrm{C}$ ratio (1.71) than the best herbicide treatment penoxsulam + cyhalofop butyl with corresponding cost of cultivation, net return and B:C ratio values of $\mathrm{Rs} 44,145 / \mathrm{ha}$, Rs $39,155 /$ ha and 1.89 , respectively.

\section{References}

Bastiaans EW, Krop VMJ, Kempuchetty N, Rajan A, and Migo TR. 1997. Can simulation models help design rice cultivars that are more competitive against weeds? Field Crops Res. 51, 101-111

Government of Odisha, 2017-18. Odisha Economic Survey 2017-18

Rajkhowal DJ, Borah N, Borua IC and Dekha NC. 2006. Effect of Pyrazosulfuronethyl on weeds and productivity of transplanted rice during rainy season, Indian Journal of Weed Science, 38:2628

Singh G, Singh Y, Singh VP, Johnson DE and Mortimer M. 2005. System-level effects in weed management in rice-wheat cropping in India, In "Proceedings of British Crop Production Council (BCPC) Crop Science and Technology Congress", 1:545-550

Oerke EC and Dehne HW. 2004. Safeguarding production losses in major crops and the role of crop protection, Crop Protect, 23,275-285

\section{How to cite this article:}

Aurobindo Mohanta and Behura, A. K. 2020. Bio-Efficacy of Different Herbicides on Weed Dynamics, Growth and Grain Yield of Transplanted Rice (Oryza sativa L.) in Odisha, India. Int.J.Curr.Microbiol.App.Sci. 9(04): 2258-2563. doi: https://doi.org/10.20546/ijcmas.2020.904.307 